\title{
Conceptions about Teaching and Learning Held by EFL Teachers and Learners in China
}

\author{
Hongbo Qi \\ Eastern Institute of Technology Data Science and Communication College, Zhejiang Yuexiu University, Shaoxing, China \\ Email: 20141076@zyufl.edu.cn
}

How to cite this paper: Qi, H. B. (2022). Conceptions about Teaching and Learning Held by EFL Teachers and Learners in China. Open Journal of Social Sciences, 10, 314-325.

https://doi.org/10.4236/jss.2022.102023

Received: January 24, 2022

Accepted: February 22, 2022

Published: February 25, 2022

Copyright (c) 2022 by author(s) and Scientific Research Publishing Inc. This work is licensed under the Creative Commons Attribution International License (CC BY 4.0).

http://creativecommons.org/licenses/by/4.0/

\begin{abstract}
Different from traditional research in related topic which focuses on the relation between teacher's epistemological beliefs and conceptions about teaching and learning, and teaching motivation, self-efficacy and so on, this article aims at finding out whether Chinese EFL teachers and learners share similar beliefs or conceptions about language teaching and learning. The same questionnaire made by Chan and Elliott (2004) is applied and Excel and SPSS are employed in statistics. The results of the survey show that teachers and learners in Chinese foreign language class share similar conceptions about language teaching and learning, but the degree they agree with constructivist conceptions is very significantly different with the student being more convinced of constructivist perspectives. The results are discussed and the implications of the survey are suggested.
\end{abstract}

\section{Keywords}

Epistemological Beliefs and Conceptions, Teaching and Learning, Constructivist Conception, Traditional Conception

\section{Introduction}

Epistemological beliefs and conceptions about teaching and learning are a topic firstly discussed in the field of educational psychology (Schommer, 1990, 1994; Williams \& Burden, 1997; Benjamin, 2003; Chan \& Elliott, 2004), it then becomes a new trend in language teacher education/training in applied linguistics (Smith, 1996; Richards, Ho, \& Giblin, 1996; Richards, 1998; Richards, Gallo, \& Renandya, 2001; Chan, 2007; Wilkinsona et al., 2017; Kırmızı \& Irgatoğlu, 2021). Different theories and categories are displayed and several important conclusions are drawn. While most traditional research in this topic focuses on the relation between teacher's epistemological beliefs and conceptions about 
teaching and learning, and teaching motivation, self-efficacy and so on, this article sets out to find out whether language teachers and learners in Chinese context share similar beliefs or conceptions about language teaching and learning.

I begin in Section 2 with a brief introduction of the theoretical background of the survey and synthesize some terms in the literature. I then point out the hypothesis as well as the purpose of this study in Section 3. In Section 4, I elaborate the method of the survey in respondents, research instruments, and procedures. After a statistical analysis based on Excel and SPSS is followed in Section 5, I then discuss the result of the survey in detail in Section 6. Lastly, together with the conclusion, I point out the limitations of this survey study and implications for teachers and students respectively.

\section{Theoretical Background of the Survey}

As a prime advocate of the research on epistemological beliefs and conceptions about teaching and learning, Schommer (1990) firstly carried out a study in 117 junior college students and 149 university students, then he hypothesized five beliefs about the nature of knowledge and learning, they include belief in: omniscient authority, certain knowledge, simple knowledge, quick learning and fixed ability (Schommer, 1994: p. 300). Table 1 illustrated the result of his and some other researchers' investigations into student beliefs (Schommer, 1994: p. 301). After synthesizing the literature in this field, she then pointed out that epistemological beliefs affect the degree to which individuals: 1) actively engage in learning, 2) persist in difficult tasks, 3) comprehend written material, and 4) cope with ill-structured domain (Schommer, 1994: p. 302).

Enlightened by the work of Schommer and other researchers, Chan and Elliott (2004) identified four epistemological beliefs dimensions (innate/fixed ability, learning effort/process, authority/expert knowledge and certainty knowledge) and two teaching and learning conceptions (traditional and constructivist conceptions). According to them, epistemology/epistemological belief was "an area of philosophy concerned with the nature and justification of human knowledge"

Table 1. Schommer's (1990) hypothesized epistemological dimensions.

1 Source of knowledge: From knowledge is handed down by omniscient authority to knowledge is reasoned out through objective and subjective means.

2 Certainty of knowledge: From knowledge is absolute to knowledge is constantly evolving.

3 Organization of knowledge: From knowledge is compartmentalized to knowledge is highly integrated and interwoven.

4 Control of learning: From ability to learn is genetically predetermined to ability to learn is acquired through experience

5 Speed of learning: From learning is quick or not-at-all to learning is gradual process.

(Schommer, 1994: p. 301). 
(2004: p. 818), while the conceptions about teaching and learning were referred to as "the belief held by teachers about their preferred ways of teaching and learning" (ibid: 819). After a survey study of a sample of Hong Kong teacher education students, they reported the significant correlations between innate/fixed ability, authority/expert knowledge and certainty knowledge with traditional conception, and learning effort/process with constructivist conception. Therefore, they conclude teachers' conceptions about teaching and learning are belief-driven.

In fact, "teacher belief" has been widely discussed in the field of teacher education in recent decades, especially in second or foreign language teacher education. Shavelson and Stern (1981, cited by Richards, 1998: p. 66) suggested that what teachers indeed was governed by what they thought. Teachers' theories and beliefs were seen as "a filter through which a host of instructional judgments and decisions are made" (Ridchards, 1998: 66). Smith (1996: pp. 197-216) discussed the consistence between ESL teachers' instructional decisions and expressed beliefs and the influence of personal belief systems on their rank of the objectives for the course they taught. Richards, Ho, and Giblin (1996: pp. 242-259) illustrated the way in which teachers' personal theories influence their perception and evaluation of their own teaching from three perspectives: teacher-centered perspective, curriculum-centered perspectives and learner-centered perspectives.

Although conceptions/beliefs about teaching and learning might be a topic that is discussed mainly in the field of teacher education, for second or foreign language teaching methodologists, they may be related to perspectives on language teaching and learning, and therefore affect teachers in adopting different teaching approach. According to Smith (1996), there are two different perspective of language learning that are dominating in ESL pedagogy: a productive view and process view:

In theoretical models reflecting a product-oriented or formalist position, language is viewed primarily as an object to be mastered. Two mainstream approaches adopting this perspective are the audio-lingual method and the cognitive code method, focusing on learner mastery and accurate use of discrete language items through a transmission model of teaching. On the other hand, underlying the process-oriented models there is an assumption that language is an activity, not a product, and emphasis is placed on the use of language for communicative purposes. The perspective underlies both the communicative language teaching approach and task-based teaching. These process-oriented teaching approaches emphasize student-centered classrooms in which teachers are facilitators rather than directors and activities which focus on communication of meaning rather than accuracy and form (Smith, 1996: pp. 197-198).

Similarly, in discussing the differences between traditional and constructivist conceptions, Chan and Elliott assert:

In the Traditional Conception, teaching is seen as a non-problematic transfer of knowledge or an untransformed manner from an expert to a novice. Learning is then the absorption of this. In the Constructivist Conception, learning is the 
creation of acquisition of knowledge by the learner through reasoning and justification. Teaching is a provision and facilitation of the learning process rather than transmission of knowledge (2004: p. 821).

It is an obviously beyond my capacity to synthesize various terms and opinions in the forementioned literature in epistemological beliefs and conceptions about teaching and learning. However, the following tentative conclusion might be drawn according to my understanding:

Conceptions about teaching and learning are highly related to epistemological beliefs held by teachers and learners; Conceptions about teaching and learning can be divided into two categories: traditional (product-oriented by Smith, 1996 or teacher-centered and curriculum-centered by Richards et al.) and constructivist (process-centered by Smith or student-centered by Richards et al., 1996).

\section{Rationale and Purpose of the Survey}

Despite the fact that numerous research has been done in the field of epistemological beliefs and conceptions about teaching and learning, few (if any) discussed and explored whether teachers and learners share same beliefs or conceptions about teaching and learning. While it is agreed that epistemological beliefs and conceptions have a positive influence on teachers' actions and behaviors in class, the same may be true for students. If the students share the same beliefs and conceptions with the teacher, the efficacy of classroom instruction may be promoted. This survey study in a Chinese context may shed some light on what both Chinese foreign language teachers and learners believe in language teaching and learning. I adopted the same questionnaire constructed by Chan and Elliott (2004) in exploring the query whether teachers and students in Chinese foreign language context agree with each other in conceptions about language teaching and learning.

The purpose of the survey is to find out whether teachers and students in Chinese foreign language class share similar beliefs/conceptions about language teaching and learning. As it is widely accepted by teachers that whatever they do in the class, without the consensus and acceptance of the students, the teachers' instructions can never be followed by the students. Similar epistemological beliefs and conceptions about teaching and learning are desirable. The hypotheses set before this survey are: 1) teachers and learners in Chinese foreign language class share similar conceptions about language teaching and learning; 2) the degree to which they agree with conceptions about language teaching and learning is similar between teachers and students.

\section{Method}

A 30-item questionnaire was conducted with 70 English majors and 40 English teachers. The respondents were asked to rate the degree to which they agreed with the 30 statements in the questionnaire. The following subsections give a brief description of the participants, the procedure and the research instrument 
of the survey.

\subsection{Respondents}

The 70 students in my survey study were junior students majored in English at Zhejiang Yuexiu University. They were randomly selected among 560 juniors in English Department. They had learned English for more than 8 years and had grasped at least 5000 - 6000 English words. I chose junior English majors firstly because they are upper-mediate English learners and therefore can understand the 30-item questionnaire in English without misunderstanding them. Secondly, I know about $30 \%$ - 50\% of the students would be English teachers in 2 years after they graduate from the university, and hence their opinions are also important for the study of teacher education. The 40 teachers were also selected randomly among 90 teachers in the same Department, 12 (30\%) of whom had taught English for more than 10 years, 16 (40\%) of whom more than 5 years, and $12(30 \%)$ of whom less than 5 years.

\subsection{Research Instruments}

The questionnaire I adopted in this survey study is a 30-item one used by Chan and Elliott (2004), with different purpose though. For Chan and Elliott (2004), it served as a tool to elicit teacher education students' conceptions, one of the two questionnaires in a comparative study of the correlation between epistemological beliefs and conceptions about teaching and learning. For me, it is the only a means through which I understand the possible difference in conceptions about learning between teachers and students. Both teachers and students were asked to rate each statement in the same questionnaire with 5 if they strongly agreed, 4 if they agreed, 3 if they neither agreed nor disagreed, 2 if they disagreed and 1 if they strongly disagreed. The 30 statements in the questionnaire could be divided into two categories: traditional conception and constructivist conception. In order to make this division less obvious, I just distributed the statements in a distorted order, so that statement one may belong to constructivist conception while statement two may belong to traditional conception, and so on.

\section{Data Collection and Analysis and Results}

70 questionnaires were delivered to students and 68 valid data were collected, 40 questionnaires were delivered to teachers and we collected 32 valid responses. Statistical analyses were based on software Excel and SPSS. Independent-Samples $\mathrm{T}$ Test was applied in dealing with all the data from both students and teachers at Zhejiang Yuexiu University. Table 2 shows the average score the teachers and students gave to each statement. A further analysis of the two perspectives of conceptions of teaching and learning, namely constructivist and traditional perspectives are shown in Table 3.

As can be seen from Table 3, teachers score high (4.06) on statements containing constructivist perspective on teaching and learning, while low (2.44) on 
Table 2. Results of the questionnaire conducted with teachers and students at Shaoxing University in December, 2006.

\begin{tabular}{|c|c|c|c|}
\hline Statements & Perspectives & Teachers & Students \\
\hline $\begin{array}{l}\text { 1) The ideas of students are important and } \\
\text { should be carefully considered }\end{array}$ & Constructivist & 4.16 & 4.63 \\
\hline $\begin{array}{l}\text { 2) The major role of a teacher is to transmit } \\
\text { knowledge to students }\end{array}$ & Traditional & 3.31 & 3.37 \\
\hline $\begin{array}{l}\text { 3) Learning occurs primarily from drilling and } \\
\text { practice }\end{array}$ & Traditional & 3.00 & 3.90 \\
\hline $\begin{array}{l}\text { 4) During the lesson, it is important to keep } \\
\text { students confined to the textbooks and the desks }\end{array}$ & Traditional & 2.03 & 1.94 \\
\hline $\begin{array}{l}\text { 5) Teachers should have control over what } \\
\text { students do all the time }\end{array}$ & Traditional & 2.00 & 1.60 \\
\hline $\begin{array}{l}\text { 6) Effective teaching encourages more } \\
\text { discussion and hands on activities for students }\end{array}$ & Constructivist & 4.00 & 4.41 \\
\hline $\begin{array}{l}\text { 7) Teaching is simply telling, presenting or } \\
\text { explaining the subject matter }\end{array}$ & Traditional & 1.94 & 2.13 \\
\hline $\begin{array}{l}\text { 8) I have really learned something when I can } \\
\text { remember it later }\end{array}$ & Traditional & 2.91 & 3.62 \\
\hline $\begin{array}{l}\text { 9) Good teaching occurs when there is mostly } \\
\text { teacher talk in the classroom }\end{array}$ & Traditional & 1.94 & 2.22 \\
\hline $\begin{array}{l}\text { 10) Students have to be called on all the time to } \\
\text { keep them under control }\end{array}$ & Traditional & 2.16 & 2.21 \\
\hline $\begin{array}{l}\text { 11) Students should be given many } \\
\text { opportunities to express their ideas }\end{array}$ & Constructivist & 4.25 & 4.38 \\
\hline $\begin{array}{l}\text { 12) Learning means remembering what the } \\
\text { teacher has taught }\end{array}$ & Traditional & 2.28 & 2.37 \\
\hline $\begin{array}{l}\text { 13) A teacher's major task is to give students } \\
\text { knowledge/information, assign them drill and } \\
\text { practice, and test their recall }\end{array}$ & Traditional & 2.88 & 3.28 \\
\hline $\begin{array}{l}\text { 14) Learning mainly involves absorbing as } \\
\text { much information as possible }\end{array}$ & Traditional & 3.47 & 3.24 \\
\hline $\begin{array}{l}\text { 15) Good students keep quiet and follow } \\
\text { teacher's instruction in class }\end{array}$ & Traditional & 2.22 & 2.16 \\
\hline $\begin{array}{l}\text { 16) In good classrooms there is a democratic and } \\
\text { free atmosphere which stimulates students to } \\
\text { think and interact }\end{array}$ & Constructivist & 4.41 & 4.35 \\
\hline $\begin{array}{l}\text { 17) The traditional method for teaching is best } \\
\text { because it covers more information/knowledge }\end{array}$ & Traditional & 2.78 & 2.25 \\
\hline $\begin{array}{l}\text { 18) Every student is unique or special and } \\
\text { deserves an education tailored to his or her } \\
\text { particular needs }\end{array}$ & Constructivist & 3.59 & 4.15 \\
\hline
\end{tabular}




\section{Continued}

19) Good teachers always encourage students to think for answer themselves

Constructivist $\quad 4.16 \quad 4.06$

20) The focus of teaching is to help students construct knowledge from their learning experience instead of knowledge communication

21) It is best if teachers exercise as much authority as possible in the classroom

Traditional

22) Different objectives and expectations in learning should be applied to different students

Constructivist

23) Teaching is to provide students with accurate and complete knowledge rather than encourage them to discover it

Traditional

24) A teacher's task is to correct learning misconceptions of students right away instead of verify them for themselves

25) Teaching simply means practicing the ideas from lectures without questioning them

26) No learning can take place unless students are controlled

Traditional

27) Good teachers always make their students feel important

28) Instruction should be flexible enough to accommodate individual differences among students

29) It is important that a teacher understands the feelings of the students

30) Learning means students have ample opportunities to explore, discuss and express their ideas

Table 3. Results of total average of two perspectives held by teachers and students.

\begin{tabular}{ccccccccc}
\hline & \multicolumn{4}{c}{ Constructivist } & \multicolumn{4}{c}{ Traditional } \\
\cline { 2 - 9 } Group & $\mathrm{N}$ & Mean & $\begin{array}{c}\text { Std. } \\
\text { Deviation }\end{array}$ & $\begin{array}{c}\text { Std. } \\
\text { Error Mean }\end{array}$ & $\mathrm{N}$ & Mean & $\begin{array}{c}\text { Std. } \\
\text { Deviation }\end{array}$ & $\begin{array}{c}\text { Std. } \\
\text { Error Mean }\end{array}$ \\
\hline teachers & 384 & 4.06 & 0.831 & 0.042 & 576 & 2.44 & 1.006 & 0.042 \\
students & 816 & 4.24 & 0.850 & 0.030 & 1224 & 2.48 & 1.149 & 0.033 \\
\hline
\end{tabular}

statements representing traditional perspectives on teaching and learning. A similar trend is displayed by students who rate high (4.24) on constructivist conceptions and low (2.48) on traditional conceptions. This shows both teachers and students in China are more constructivism-oriented. Therefore, the first hypothesis is accepted in that Chinese teachers and students both believe in con- 
structivist conception. However, statistical analysis on Independent-Samples $\mathrm{T}$ Test reveals that there is a very significant difference in the degree to which how much both teachers and students agree with constructive conceptions while no significant difference in traditional conceptions are found. Table 4 illustrates that students are significantly highly constructivism-oriented than teachers. Therefore, the second hypothesis that the degree to which they agree with conceptions about language teaching and learning is same among teachers and students is rejected. In the next section, I will discuss what the results of these statistical data mean.

\section{Discussion}

As is discussed about, the purpose of this survey study is to find out whether: 1) teachers and learners in Chinese foreign language class share similar conceptions about language teaching and learning; 2) the degree to which they agree with conceptions about language teaching and learning is similar among teachers and students. The results of the survey show that Chinese teachers and students both believe in constructivist conception, and that there is a very significant difference in the degree to which how much both teachers and students agree with constructive conceptions while no significant difference in traditional conceptions are found. I will elaborate the reason of these findings in two parts.

\subsection{Both Teachers and Students in Mainland China Believe in Constructivist Conceptions}

Statistical analysis of the data gathered from the questionnaire shows that, on the whole, both teachers and students believe in constructivist conceptions about teaching and learning. Table 3 shows that the average score on constructivist statements the teachers gave was 4.06, in contrast, a relatively low score of 2.44 was given on traditional statements. Similarly, the students in the questionnaire give a mean score of 4.24 on constructive conceptions while another low score of 2.48 on traditional conceptions. This result, however, is strikingly different from the one made by Chan and Elliot (2004: p. 828), who claimed that teacher education students in Hong Kong "did not exclusively believe in the Traditional or Constructivist Conception about teaching and learning". As a matter of fact, the average score on constructivist and traditional conceptions by Hong Kong novice teachers were 1.86 and 2.63 respectively.

Table 4. Result of independent-samples t test.

\begin{tabular}{ccccccc}
\hline Category & respondents & $\mathrm{N}$ & Mean & $\begin{array}{c}\text { Std. } \\
\text { Deviation }\end{array}$ & $\mathrm{t}$ & $\begin{array}{c}\text { Sig. } \\
\text { (2-tailed) }\end{array}$ \\
\hline $\begin{array}{c}\text { Constructivist } \\
\text { conception }\end{array}$ & teachers & 384 & 4.06 & 0.831 & $-3.55^{* *}$ & 0.000 \\
$\begin{array}{c}\text { Traditional } \\
\text { conception }\end{array}$ & teachers & 576 & 2.44 & 1.006 & & \\
\hline
\end{tabular}


Both Hong Kong and mainland China today are unique in that people in these two areas are exposed to the interactive influence of traditional Confucian and western idea. Why are there such striking differences in conceptions the two surveys?

Firstly, the respondents to the same questionnaire are different. The participants in Chan and Elliot's (2004) survey were novice teachers (teacher education students) in Hong Kong, while the respondents in my survey were students and teachers at university. Participants in both surveys differ in age and experience as teachers or students.

Secondly, in modern mainland China, it is not Confucianism, but Maoism that has more influence the current two generations (teachers and students). It is beyond my capacity to elaborate Maoism in this paper, but one thing is certain: Maoism asserts that everything old should be revolutionized, and of course Confucian is of no exception. A good case in point is the Culture Revolution led by Mao in the 1960s and 1970s. Most of the teachers in my survey were students at that time, when "to doubt and to refute everything old" was guiding principle for students. Therefore, it is not surprising to find out anything like "rebelling" in the deep mind of teachers today.

As one of most important developing countries in the world, China is now undergoing a critical process of "opening-up" and "reforming", learning from the West has become a vogue. It is, again, not surprising for both Chinese teachers and students bear in mind such western conceptions as Humanism and Constructivism.

\subsection{Students Respond More Positively to Constructivist Conceptions}

Even though constructivist conceptions are widely accepted among teachers and students, there is, according to statistical analysis, very significant difference in degree between these two groups. The degree to which students believe in constructivist conceptions is significantly high than that to which teachers do.

It is widely believed that respecting the old and authority figures is highly valued in China, yet my recent survey shows that Chinese students do not quite see teachers as an authority figure, and they display similar degree in their preference to autonomy in language learning to their western counterparts (Qi, 2004: pp. 90-92). Today's young generation, as Chan and Elliott (2004: p. 827) point out, may not abide authority figures as strongly as the older generation. Family nurture since 1980s has become more liberal and individualized. The young generation has more autonomy in deciding whether they should follow what their parents and teachers say. That is why students' conception about teaching and learning are more constructivist than that of teachers. I will discuss the implication of the survey study in the next section.

\section{Conclusion and Implication}

Before drawing a conclusion of the study, I would like to point out two limita- 
tions of this survey.

Firstly, there is a limitation of respondents. As is mentioned above, the subjects of my survey are 70 junior university students majored in English, and 40 Chinese university teachers of English, most of whom have been teaching English for years. Whether or not they represent "Chinese teachers and students" requires the testimony from further larger-scaled investigations.

Secondly, the survey may not be comprehensive. As a teacher of English for more than 20 years, my intuition to the result of the survey is that the degree to which both teachers and students believe in constructivism might be too high. Maybe I should have followed an interview or open-ended questionnaires so as to disclose whether they rate high on constructivist conception only because they really think so.

Despite the drawbacks, the survey study does disclose that fact both Chinese EFL teachers and students believe more in constructivist conceptions about language teaching and learning at university level. It also points out that those university students are more convinced of the constructivist conception than their teachers.

Implications can be drawn for language teachers and learners respectively.

For teachers, it is important to know that the students they teach believe in constructivist conception about language learning. Therefore, more student-centered or process-oriented approaches should be taken; their classroom instruction should be more communicative and task-based. According another survey I made in $2001,71 \%$ of the students at a university thought that English class was either teacher-centered or textbook-centered and therefore boring and dull (cited from an unpublished application to a teaching reform project funded by State Education Department aimed at reforming English classroom instruction in 2004). It might be possible that within 5 years, teachers as a group have changed their belief in teaching and learning from a traditional one to constructivist one. It might also be the fact that although teachers believe in constructivist conceptions, they behave traditionally in practice for some reason, which, obviously is beyond the scope of this paper and requires further investigation. However, I would take the students' comment as a reminder for teachers, because as Benjamin (2003: p. 2) pointed out, "it is also recognized that it is difficult to change teacher's beliefs". So, a sensible solution for teachers to follow might be more reflective on their practices as well as beliefs, and be more approachable to their students and be readier to negotiate with students on matters such as teaching plan and task setting.

For students, it is equally important to know that their teachers are at least constructivist in mind. Thereupon, they should take more initiative in their study. Needless to say, as is discussed above, Maoism used to influence greatly the generation of most teachers today, but not as much to the young generation. Chinese society is now under an integrative influence of Confucianism and Western ideas. On one hand, students are convinced of constructivist conceptions, on the other hand, as a virtue in traditional Chinese culture, they also be- 
have in a way that they as teachers as authority figures. Therefore, the significance of students' understanding that most teacher are constructivists lies in fact that they will claim more autonomy in language learning. Thus, as Schommer (1994) pointed out, the students should engage in learning more actively, persist more firmly in difficult tasks and cope more sophisticatedly with ill-structured domain in language learning.

As for suggestions on actual teaching practice, it is always necessary for both teachers and students to share respective beliefs and concepts about teaching and learning through a series of communicative and tasked-based learning activities. A reflective teacher is always ready to take student-centered or process-oriented approaches in preparing the students for a life-long learning in their future career. A constructivist teacher is certainly willing to get students involved in the plan of teaching as well as the process of learning.

\section{Conflicts of Interest}

The author declares no conflicts of interest regarding the publication of this paper.

\section{References}

Benjamin, J. (2003). Revision and Validation of the Revised Teacher Beliefs Survey. In The Annual Meeting of the American Educational Research Association. ERIC Document Reproduction Service No. 476126.

Chan, K., \& Elliott, R. G. (2004). Relational Analysis of Personal Epistemology and Conceptions about Teaching and Learning. Teaching and Teacher Education, 20, 817-831. https://doi.org/10.1016/j.tate.2004.09.002

Chan, K.-W. (2007). Hong Kong Teacher Education Students' Epistemological Beliefs and Their Relations with Conceptions of Learning and Learning Strategies. The Asia Pacific-Education Researcher, 16, 199-214. https://doi.org/10.3860/taper.v16i2.265

Kırmızıa, Ö., \& Irgatoğlu, A. (2021). An Investigation of the Relation between Pre-Service EFL Teachers' Epistemological Cognition and Teaching Approaches. Manisa Celal Bayar University Journal of Social Sciences, 19, 217-232. https://doi.org/10.18026/cbayarsos.874649

Qi, H. (2004). A Survey on Autonomy Awareness of Second Language Learners in China. Foreign Language Education, 25, 90-92.

Richards, J. C. (1998). Beyond Training. Cambridge University Press.

Richards, J. C., Gallo, P. B., \& Renandya, W. A. (2001). Exploring Teachers' Beliefs and the Processes of Change. The PAC Journal, 1, 41-62.

Richards, J. C., Ho, B., \& Giblin, K. (1996). Learning How to Teach in the RSA Cert. In D. Freeman, \& J. C. Richards (Eds.), Teacher Learning in Language Teaching (pp. 242-259). Cambridge University Press.

Schommer, M. (1990). Effects of Beliefs about the Nature of Knowledge on Comprehension. Journal of Educational Psychology, 82, 498-504.

https://doi.org/10.1037/0022-0663.82.3.498

Schommer, M. (1994). Synthesizing Epistemological Belief Research: Tentative Understanding and Provocative Confusion. Educational Psychology, 6, 293-319.

https://doi.org/10.1007/BF02213418 
Smith, D. B. (1996). Teacher Decision Making in the Adult ESL Classroom. In D. Freeman, \& J. C. Richards (Eds.), Teacher Learning in Language Teaching (pp. 197-216). Cambridge University Press.

Wilkinsona, I. A. G., Reznitskayab, A., Bourdagec, K., Oylerd, J., Glinab, M., Drewrya, R., Kima, M.-Y., \& Nelsone, K. (2017). Toward a More Dialogic Pedagogy: Changing Teachers' Beliefs and Practices through Professional Development in Language Arts Classrooms. Language and Education, 31, 65-82.

https://doi.org/10.1080/09500782.2016.1230129

Williams, M., \& Burden, R. L. (1997). Psychology for Language Teachers. Cambridge University Press. 